\title{
Evaluation of Ultrasound Attenuation Characteristics of Human Cataract
}

\author{
Alvydas PAUNKSNIS, Skaidra KURAPKIENE \\ Department of Ophthalmology, Institute for Biomedical Research \\ Kaunas University of Medicine \\ Eiveniu 4, LT-3007, Kaunas, Lithuania \\ e-mail:apaun@medi.lt \\ Audris MAČIULIS \\ Department of Applied Electronics, Kaunas University of Technology \\ Studentu 50-302, LT-3031, Kaunas, Lithuania \\ e-mail:maciul@ktu.lt \\ Marija-Liucija PAUNKSNIENE \\ Department of Anatomy and Histology, Lithuanian Veterinary Academy \\ e-mail: oftalmolog@lva.lt.
}

Received: July 2003

\begin{abstract}
Cataract is very frequent disease of human eye and the diagnosis of this disease is not difficult. However, it is important to describe it quantitatively, but it is difficult using only the slit lamp. Ultrasound examinations are widely used in ophthalmology. Piezoelectric crystals generate ultrasound waves of 5-50 MHz. Short pulses of 2 to 3 cycles are sent from transducer into the eye. These pulses go through the tissues of the eye with the speed that is inversely proportional to the density and elasticity of the eye. Acoustic parameters of biologic tissues are described by velocity and attenuation coefficient. It is known that in soft tissues the attenuation coefficient is approximately proportional to the frequency - high frequency components of echoes are attenuated more than the lower frequency components. Results of ultrasound attenuation characteristics of human nuclear cataract are presented. It was shown that ultrasound attenuation of nuclear cataract could be used as "second opinion" for physicians decision support.
\end{abstract}

Key words: ultrasound attenuation, nuclear and diabetic cataract, acoustic parameters, digital signal processing.

\section{Introduction}

Cataract is one of the earliest known disabling conditions of the eye. In most cases, the appearance of a cataract seems to be a result of certain biochemical changes in the lens, associated with aging, but the nature and mechanism of such changes is thus far unestablished, at least in humans. It is known that cataracts may also form as a consequence of certain inborn metabolic derangements, including diabetes mellitus. It would be fair 
to conclude that diabetes, especially when poorly controlled, does constitute a cataractogenic factor, either by itself or synergistically with other factors (nutritional status of the patient, age, genetic variations) known to participate in the formation of cataracts. However, it is important to describe it quantitatively, but it is difficult using only the slit lamp.

Ultrasound examinations are widely used in ophthalmology. Piezoelectric crystals generate ultrasound waves of 5-50 MHz. Short pulses of 2 to 3 cycles are sent from transducer into the eye. These pulses go through the tissues of the eye with the speed that is inversely proportional to the density and elasticity of the eye.

Acoustic parameters of biologic tissues are described by velocity and attenuation coefficient. It is known that in soft tissues the attenuation coefficient is approximately proportional to the frequency - high frequency components of echoes are attenuated more than the lower frequency components (Sugata et al., 1992). Ultrasound pulses are attenuated as the result of absorption and scattering as it goes through the tissue (Tabandeh $e t$ al., 2000).

Normal lens is acoustically homogenous and clear. It's characteristics change according to the density of cataract that is due to changes in tissue density and structure (molecular weight and size) (Tabandeh et al., 2000). The crystallins are the main structure of the human lens and constitute approximately $90 \%$ of the total protein content (Benedek, 1997). Their structural function is to assist in maintaining the proper refractive index of the lens and its transparency (Delay and Tardieu, 1983). According to molecular weight there are $\alpha$-crystallins (over $200 \mathrm{kDa}$ ), $\beta$-crystallins $(40-160 \mathrm{kDa}$ ) and $\gamma$-crystallins (about $20 \mathrm{kDa}$ ).

Oxidative damage to the lens proteins is a major factor leading to cataract formation the aggregation of the lens proteins randomly distributed high molecular weight clusters is thought to produce sufficient fluctuation in protein density to account for opacification (Siew et al., 1981). Protein aggregation results in the development of high molecular weight aggregates of sufficient size to directly scatter light (Benedek, 1997).

In this work we intended to evaluate the influence of nuclear cataract changes to ultrasonic attenuation and try to make quantitative description of human nuclear cataract. The results of the evaluation of the influence of diabetic cataract changes to ultrasonic attenuation are presented.

\section{Materials and Methods}

The sample consisted of 28 patients who were scheduled for cataract surgery in Kaunas Medical University Eye Clinic. The age was 63-88 years, 17 women, and 11 men.

They were tested for best-corrected visual acuity, using standard Snellen chart. Cataract severity was evaluated with LOCS III grading system by the Center for Ophthalmic Research, Boston (Chylack et al., 1993) with the slit lamp comparing cataractous lenses with the standard images for grading nuclear, cortical and posterior sub capsular cataract. Before the procedure the pupils of affected eye were dilated. 
Ultrasonic Examination in-vivo

In-vivo examination of cataract lens by Mentor $^{\mathrm{TM}}$ Advent A/B ultrasonic imaging system (Advent, Norwell, MA) using 7 MHz A-mode probe was performed and ultrasound attenuation coefficient was calculated. Radio frequency echo-signals from lens were digitized by TEKTRONIX 220 oscilloscope at the sampling rate $250 \mathrm{MHz}$ and 8 bit amplitude resolution, bandwidth for analog signal was $100 \mathrm{MHz}$. Manual trigger of oscilloscope was used according to sound notice from system about the probe correct alignment to eye axis. Signal averaging was not used, but three single signals where acquired. Digitized echo signals where used for off-line processing.

The attenuation coefficient $\beta$ of the lens was obtained by the following processing (Fig. 1). The echoes from the anterior and posterior interface of the lens are cut down by the windows. In this work the assumption that attenuation frequency function is linear $\alpha(f)=\beta \cdot f$ was made. The attenuation coefficient $\beta$ was calculated from logarithmic spectra difference, taking into account spectra of echo signal from anterior $S_{A N}(f)$ and posterior $S_{P N}(f)$ nucleus interfaces, distance between interfaces $d$ and frequency range $f_{2}-f_{1}$. To the frequency function of logarithmic spectrum difference $S_{A N}(f)-S_{P N}(f)$ least-squares straight line fit $\alpha_{L}(f)$ was applied. The attenuation coefficient $\beta$ was calculated as follows: $\beta=\left[\alpha_{L}\left(f_{2}\right)-\alpha_{L}\left(f_{1}\right)\right] /\left[2 d \cdot\left(f_{2}-f_{1}\right)\right]$. Thickness of nucleus investigated was assessed taking into account first zero-crossing moments in echo signals and the sound velocity in cataract lens $c=1620 \mathrm{~m} / \mathrm{s}$ (Sugata et al., 1992; Tabandeh et al., 2000).

Echo-signals from anterior and posterior interfaces of lens nucleus where selected manually with constant time window length of $1.024 \mu \mathrm{s}$.

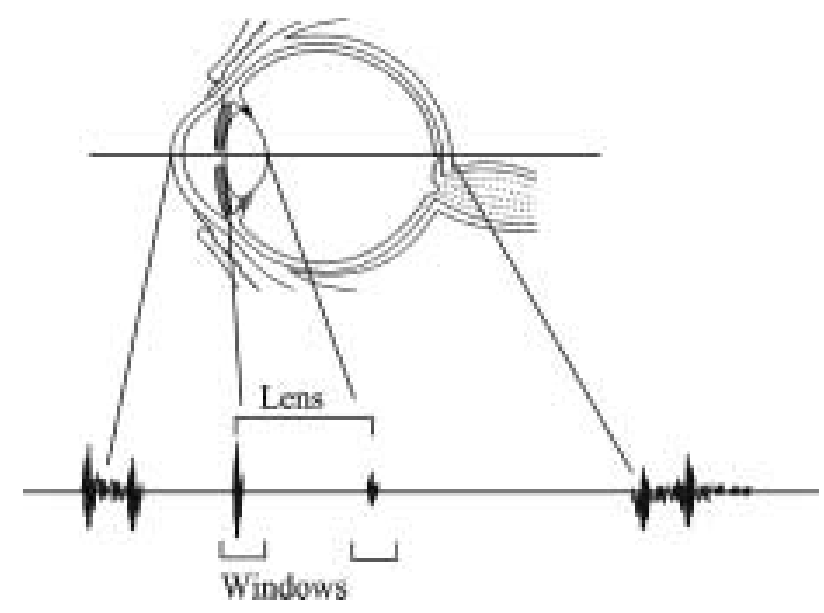

Fig. 1. Illustration of attenuation coefficient measurement system. 
Table 1

Amount of soluble proteins of human lens nucleusin different cataract severity cases

\begin{tabular}{cc}
\hline Patient group & $\begin{array}{c}\text { Soluble proteins } \\
\text { of human lens nucleus } \\
(\mathrm{mg} / 1 \mathrm{mg} \text { tissue })\end{array}$ \\
\hline $\begin{array}{l}\text { Initial cataract } \\
<4.0 \text { LOCS III; } n=12\end{array}$ \\
\hline $\begin{array}{l}\text { Advanced cataract } \\
\geqslant 4.0 \text { LOCS III; } n=16\end{array}$ \\
\hline
\end{tabular}

\section{Biochemical Examination in-situ}

In parallel the biochemical examination of lens nuclei was performed in Department of Pathochemistry of Institute for Biomedical Research of Kaunas University of Medicine (Head. Habil. Dr. Leonidas Ivanovas) (Paunksnis et al., 2001; Paunksnis et al., 2003). Extra capsular cataract extraction was performed in all the eyes, the extracted nuclei were soaked and frozen before analysis. Lens nuclei were carefully weighed and homogenized. Protein concentration was determined by the method of Lowry using bovine serum albumin as standard.

Amount of soluble lens proteins was about 50\% higher (Paunksnis et al., 2001; Paunksnis et al., 2003) in eyes with initial nuclear changes than in advanced cataract group (Table 1).

Weak and not significant inverse correlation between the visible nuclear opacities and amount of soluble nuclear proteins was found (Paunksnis et al., 2001; Paunksnis et al., $2003)$ in initial cataract group $(r=-0.37)$, but correlation calculated for all number of cases was significant $(n=28 ; r=-0.77 ; p<0.05)$ (Figs. 2-3).

These biochemical processes explains the physiology of ultrasound attenuation in non-cataract and advanced cataract lenses.

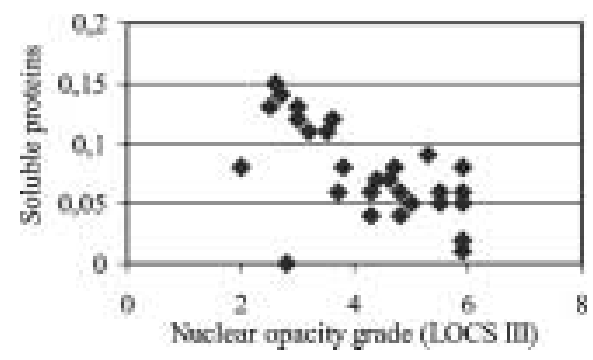

Fig. 2. Correlation between the nuclear opacities and amount of soluble proteins $(n=28$; $r=-0.77 ; p<0.05)$.

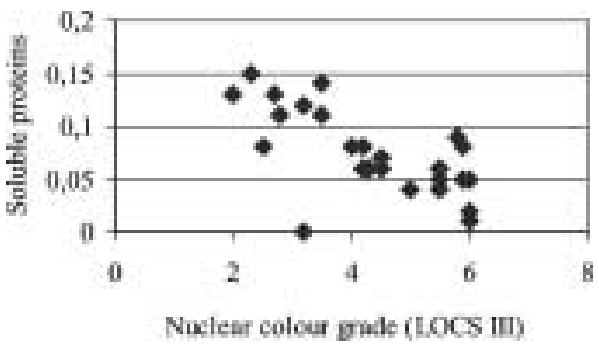

Fig. 3. Correlation between the nuclear colour and amount of nuclear soluble proteins $(n=28$; $r=-0.82 ; p<0.05)$. 


\section{Estimation of Ultrasound Attenuation in the Lens Nucleus}

The ultrasound attenuation in eye lenses was investigated. The echo signals shown in Fig. 4 and Fig. 5 illustrate the cases of non-cataract and advanced cataract lenses examination. The manually selected segments of signal for attenuation assessment are marked with line. Corresponding logarithmic spectra are presented as well.

The results of nuclear cataract investigation show that ultrasonic assessment of cataract is to be improved by changing signal acquisition technique. When rough errors in results were rejected, the measured attenuation coefficient $\beta$ in the lens nucleus was in the range of $2-15 \mathrm{~dB} /(\mathrm{cm} \mathrm{MHz})$. Correlation between attenuation and advanced nuclear opacities was $r=0.65$ (Fig. 6a). Correlation between attenuation and amount of soluble proteins was $r=-0.32$ (Fig. 6b).
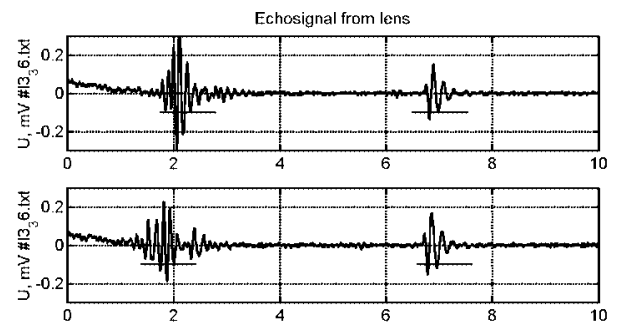

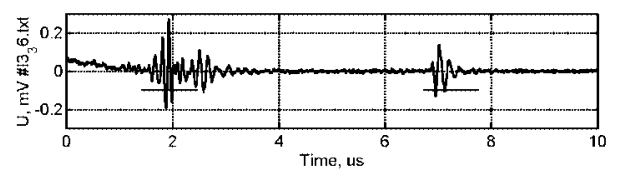

a)

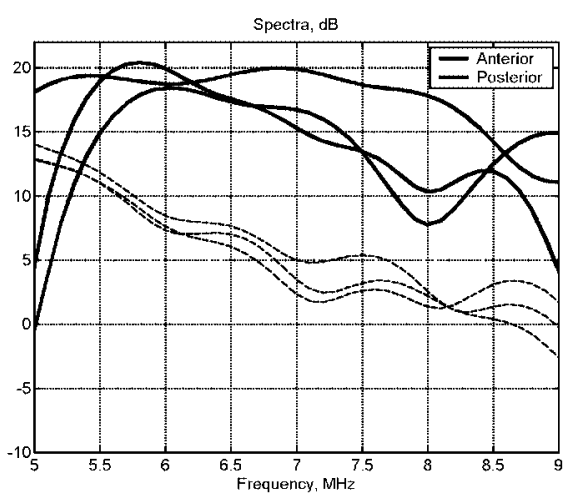

b)

Fig. 4. Waveforms of echo signals received from anterior and posterior interfaces of non-cataract lens (a) and their spectra (b).
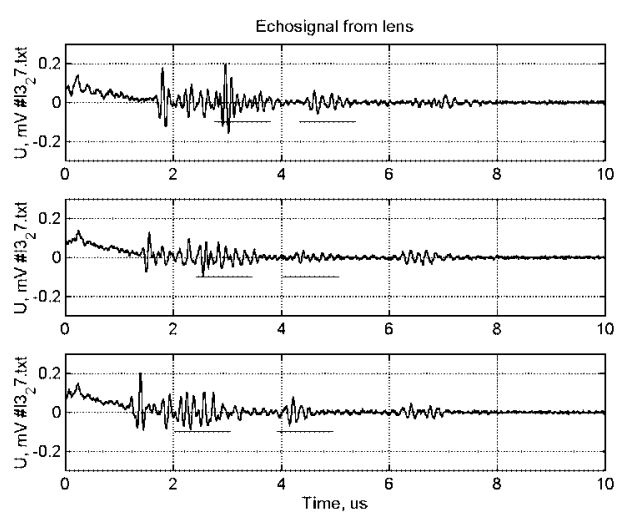

a)

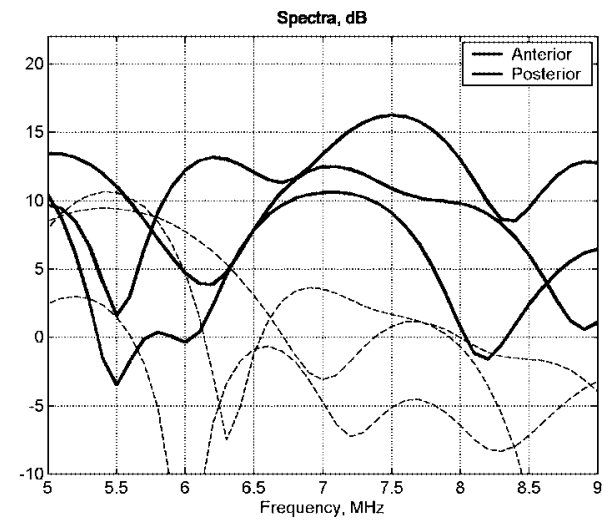

b)

Fig. 5. Waveforms of echo signals received from anterior and posterior interfaces of cataract lens (a) and their spectra (b). 


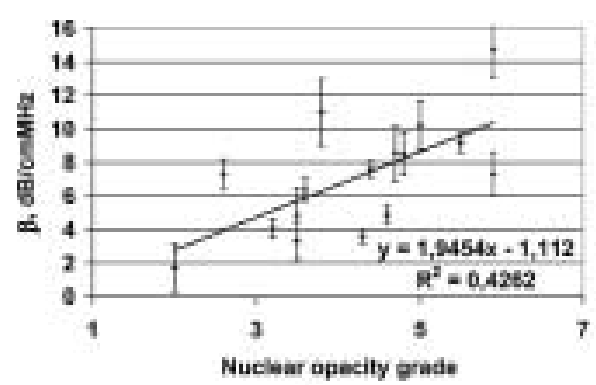

a)

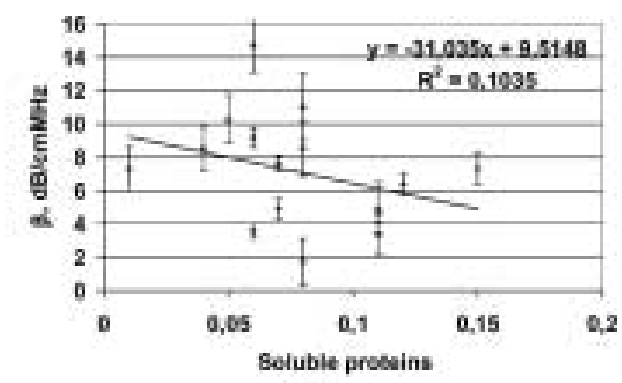

b)

Fig. 6. Increase of nuclear opacity grade (a) and decrease of concentration of soluble proteins (b) causes increased ultrasound attenuation coefficient.

\section{Estimation of Ultrasound Attenuation Coefficient of Human Diabetic Cataract}

Diabetes is a disease characterized by an excessive increase in blood sugar (glucose) caused by a relative or absolute lack of insulin in the blood. Basically, there are two forms of diabetes:

- Insulin dependent diabetes mellitus (IDDM) or type I DM: appears at a relatively early age with hereditary and autoimmune components; characteristically with acute onset, and treatment with insulin is necessary.

- Non insulin dependent diabetes mellitus (NIDDM) or type II DM: appears later in life, associated with obesity and over-eating; often discovered by chance; controllable with proper diet, body weight, and oral anti-diabetic medicine.

Exposure to hyperglycemia can cause both reversible and, if prolonged, cumulative, irreversible changes to tissue metabolism and structure. All structures in the eye are impaired by hyperglycemia. Diabetic retinopathy is the most serious complication of the diabetic microvascular abnormalities. Microvascular changes are also found in the iris and ciliary's body. Diabetes also induces metabolic disorders in the cornea, lens, muscles and nerves. Some of these impairments are of little consequence and go unnoticed by the patient or the doctor, but some changes may result in several complications following cataract surgery.

The identity of diabetic cataracts is well established in relatively younger diabetics. It is usually bilateral and consists initially of a characteristic band of subcapsular vacuoles extending to approximately one-third the depth of the superficial layers of anterior and posterior cortex. The vacuoles often are interspersed with white flaky opacities. There may also be a simultaneous appearance of water clefts and suture separations. These early stages of cataract development are ultimately followed by the appearance of more diffuse cloudiness and opacification. In adult diabetics, cataracts are characterized by cortical and nuclear involvement and it is not possible to distinguish them morphologically from the garden variety of senile cataracts. When examining the patient it is very important to describe the cataracts quantitatively, but it is difficult using only biomicroscopy. 
In this part of work we intended to evaluate the influence of diabetic cataract changes to ultrasonic attenuation and try to make quantitative description of human diabetic cataract.

The sample consisted of 25 patients ( 27 eyes) who were scheduled for cataract surgery in Eye Clinic of Kaunas University of Medicine. 14 of them are type I diabetics ( 7 with hemophthalmus, 7 - without hemophthalmus) and 13 - type II diabetics without hemophthalmus (hemophthalmus - vitreous body haemorrahges). Patients age variates between 16 and 82 years. The duration of illness changes between 7 and 32 years.

The thickness of lenses and attenuation coefficient $\beta$ were calculated for all patients in 3 groups using measurement method described above. We found that mean thickness of lenses is near the same in all diabetics groups and it changes between $2.5 \mathrm{~mm}$ and $5.1 \mathrm{~mm}$. In Fig. 5 the results of mean thickness measurement in different diabetics groups are presented. The least mean lens thickness of $3.57 \mathrm{~mm}$ was found in patients group with type I diabetics with hemophthalmus. Mean lenses thickness of $4.35 \mathrm{~mm}$ and $4.15 \mathrm{~mm}$ were found in groups with type I and type II diabetics without hemophthalmus respectively.

The ultrasound attenuation coefficients in all diabetics groups were measured as well. We have found that ultrasound attenuation coefficient is higher in the group with II-nd type diabetic cataracts, where $\beta$ changes between $5.7 \mathrm{~dB} /(\mathrm{cm} \mathrm{MHz})$ and $15.7 \mathrm{~dB} /(\mathrm{cm} \mathrm{MHz})$. The least attenuation coefficient $\beta$ is observed in I-st type diabetics with hemophthalmus, in this case $\beta=2.27-7.6 \mathrm{~dB} /(\mathrm{cm} \mathrm{MHz})$. The results of mean ultrasound attenuation coefficient calculation are presented in Fig. 7.

Results of the highest mean attenuation coefficient of $9.37 \pm 3.40 \mathrm{~dB} /(\mathrm{cm} \mathrm{MHz})$ was found in type II diabetics without hemophthalmus. Significantly lower mean values of attenuation coefficients have been found in other two cases - in type I diabetics without and with hemophthalmus $-5.82 \pm 1,22 \mathrm{~dB} /(\mathrm{cm} \mathrm{MHz})$ and $3.86 \pm 1.89 \mathrm{~dB} /(\mathrm{cm} \mathrm{MHz})$ respectively. According to these results we decided that hemophthalmus does not influence the lens ultrasound attenuation. We linked all type I diabetic cases (without and with hemophthalmus) into the same group - type I diabetics. After that the values of ul-

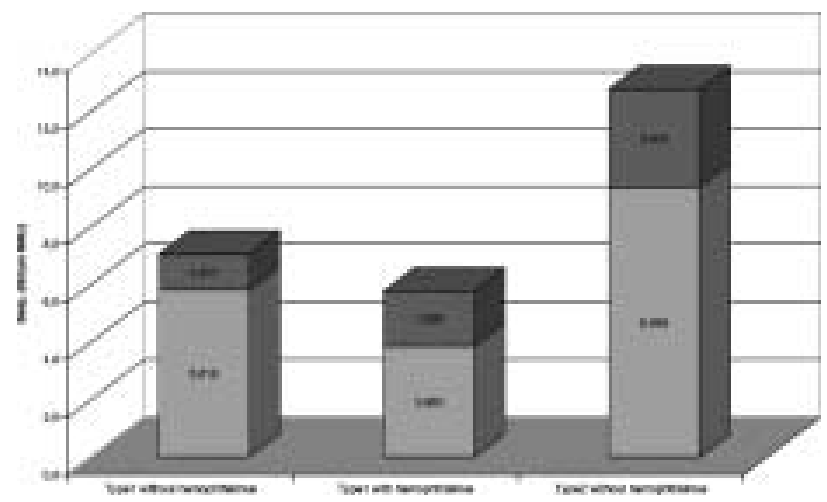

Fig. 7. The results of mean attenuation coefficients calculations in diabetics groups with different types of cataracts. 


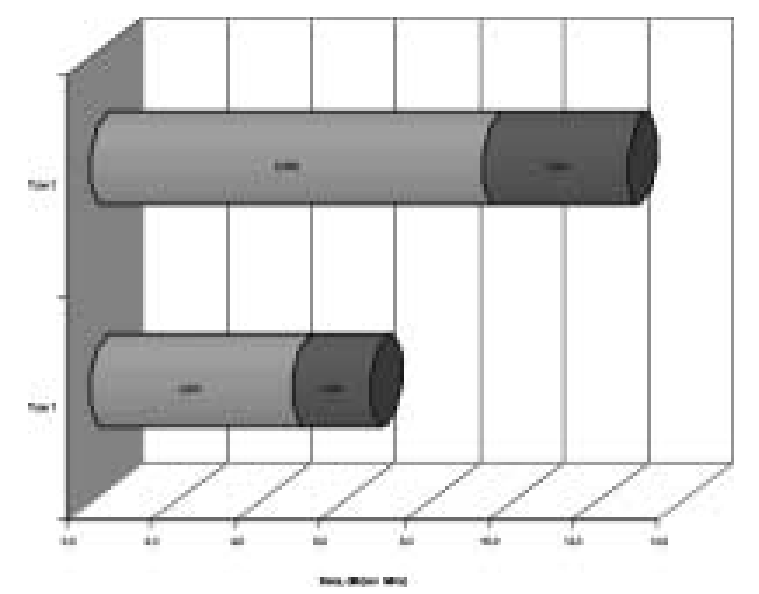

Fig. 8. The results of mean attenuation coefficient calculations in two groups with I type and II type diabetics.

trasound attenuation coefficients $\beta$ for both groups (type I and type II) were calculated. These calculations are presented in Fig. 8.

Significantly lower mean value of attenuation coefficient have been found in group with type I diabetics $-4.84 \pm 1.84 \mathrm{~dB} /(\mathrm{cm} \mathrm{MHz})$, compare with $9.37 \pm 3.40 \mathrm{~dB} /(\mathrm{cm} \mathrm{MHz})$ in group with type II diabetics. So we found that ultrasound attenuation coefficient significantly is higher in the group of type II diabetic cataracts. It may be assumed that the alteration in the properties of crystalline, increased scattering and absorption of echosignals are related to the decrease of lens transparency.

\section{Discussion}

Cataract interferes with the retinal image by scattering and absorbing light. With the age light scatter increases in all the regions of the lens with the least change in lens centre. Visual acuity is the patient's perception and it is the indirect indicator of the lens capability for the transmission of the visible light in the case there is no other pathologic changes (Nishimoto and Sasaki, 1995).

Many biochemical studies of human cataract lenses demonstrate that cataractogenesis is multifactorial process and in most cases oxidative stress initiates a series of biochemical events leading to cataract formation (Rink et al., 1995).

Rink H. and co-authors (1995) found the increased amount of water insoluble proteins in nuclear cataract lenses. This process was especially observed in the nuclear layers of cataract lenses. Redistribution of soluble cristallins from low molecular weight to high was observed in nuclear and cortical regions (Bours et al., 1995).

Progressing cataract is leading to the changes in the tissue characteristics, so we tried to use ultrasound examination and calculation of attenuation coefficient $(\beta)$ for evaluating cataract severity. 
The effect of ocular tissues on ultrasound parameters such as velocity and attenuation has been the subject of much study. Oguchi and co-authors (Oguchi et al., 1975) studied the influence of the crystalline lens on the ultrasonic field and found that the lens has absorbing, scattering and deviating effects on the propagating sound beam. In a study of ultrasound appearance of senile lens changes the correlation between the amount of opacity in the anterior cortex and nucleus with abnormal ultrasound patterns was found (Metz and Bronson, 1969). Sugata Y. and co-authors (1992) examined normal and cataract lenses and suggested the possibility of diagnosing cataract by measuring the attenuation characteristics of the lens (Siew et al., 1981).

Ultrasound attenuation by a biological medium is largely influenced by the presence of high-molecular-weight compounds and in cataract lenses increased protein aggregation contributes to the hardening of the lens and increased ultrasound attenuation (Tabandeh et al., 2000).

Considering the normal lens acoustically clear, it is reasonable that attenuation expressed by the value of $\beta$, is small and the slope of spectral difference becomes almost flat. Sugata Y. and co-authors (1992) found the normal human lens to have normal lens attenuation $0.07-0.92 \mathrm{~dB} / \mathrm{cmMHz}$, while in different cataract types $1.6-7.3 \mathrm{~dB} / \mathrm{cmMHz}$, and expressed the idea about quantitative and early detection of cataract from echo signals (Sugata et al., 1992).

In our study the difference between two spectra is obtained to eliminate the properties of the transducer and to extract attenuation characteristics. However, the spectral difference is not smooth since scattering and reflection characteristics still remain. The very important issue in lens ultrasound examination is proper alignment of acoustic axis of probe with axis of lens.

The echo signals acquired in cases of poor alignment of axes where eliminated from further analysis. Misalignment of axes is recognized from significant changes of waveform and high variability of estimated attenuation coefficient. Therefore further developments for the lens examination in-vivo are needed. To achieve better reliability of measurements the specialized triggering of acquisition of radio-frequency echo signal must be organized between $\mathrm{A} / \mathrm{B}$ imaging system and digital oscilloscope.

The changes of ultrasound attenuation accordingly to the severity of cataract could make it possible to classify it to the stages and sound attenuation can be used as a criterion for the diagnosis of cataract. It is still premature to recommend this method for evaluation of cataract stages, as it is needed to investigate the association between attenuation of the lens and different cataract types analysing many data and improving signal acquisition technique.

\section{Conclusions}

1. Visual impairment in nuclear cataract patients is related to the grade of nuclear opacity, nuclear color. Nuclear opacity and nuclear color grade is related to the decrease in the amount of soluble proteins in the lens nucleus. 
2. The association between ultrasound attenuation and amount of soluble proteins in the nucleus is significant. The analysis of the results suggests the possibility for evaluation of cataract severity by measuring value of the ultrasound attenuation coefficient.

3. The significant difference was found between ultrasound attenuation in lenses with type I and type II diabetic cataracts. Hemophthalmus does not influence the lens ultrasound attenuation. The analysis of the results suggests the possibility for investigating non-invasively diabetic cataract by measuring the ultrasound attenuation characteristics of the lens.

4. The value of ultrasound attenuation coefficient can be used for diabetic cataract differentiation. Visual function as the indirect indicator of lens light transmission was associated with the decreased amount of soluble proteins.

\section{References}

Benedek, G.B. (1997). Cataract as protein condensation disease: The proctor Lecture. Invest. Ophthalmol. Vis. Sci., 38, 1911-1921.

Bours, J., A.A. El-Layen, M.H. Emarach, H. Rink (1995). Distribution of water soluble proteins in microdisectioned cataractous lenses for one hundred Egyptian patients. Ophthalmic Res., 27(1), 54-61.

Delay, M., and A. Tardieu (1983). Short range of crystalline proteins accounts for eye lens transparency. Nature, 302, 415-417.

Metz, G.A., and N.R. Bronson (1969). Ultrasound appearance of senile lens changes. Ophthalmic ultrasound. MO, Mosby, St.Louis. pp. 218-223.

Nishimoto, K., and K. Sasaki (1995). In vivo light scattering intensity in the lens versus in vitro spectral transmission in the nuclear region. Ophthalmoc Res., 27, 1-11.

Oguchi, Y., G.B. Van Marle, F. Eijskoot, H.E. Henkes (1975). Study of the ultrasound characteristics of the lens. Bibl. Ophthalmol., 83, 252-258.

Paunksnis, A., L. Kuzmienè, S. Kurapkienè, R. Jurkonis, L. Ivanov, I. Sadauskienė, A. Lukoševičius, D. Jegelevičius (2001). Ultrasonic and biochemical characteristics of human nuclear cataract. Ultragarsas, 3(40), $11-15$.

Paunksnis, A., S. Kurapkienè, A. Mačiulis, R. Raitelaitienė, R. Jurkonis, A. Lukoševičius (2003). Estimation of ultrasound attenuation coefficient of human diabetic cataract. Ultragarsas, 1(46), 37-40.

Rink, H., A.A. El-Layen, J. Bours, M.H. Emarah (1995). Basic biochemical parameters of one hundred cataractous lenses from Egyptian patients. Ophthalmic Res., 27(1), 44-53.

Siew, E.L., D. Opalecky, F.A. Bettelheim (1981). Light scattering of normal human lens. II. Age dependence of the light scattering parametres. Exp. Eye Res, 33, 603-614.

Sugata, Y., K. Murakaami, I. Masayasu, Y. Yamamoto (1992). An application of ultrasonic tissue characterization to the diagnosis of cataract. Acta Ophthalmol., 70(204), 35-39.

Tabandeh, H., M. Wilkins, G. Thompson, D. Nassiri, A. Karim (2000). Hardness and ultrasonic characteristics of the human crystalline lens. Cataract Refract Surgery, 26, 838-841.

Waterborg, J.H., and H.R. Matthews (1984). The Lowry method for protein quantitation. Meth. Mol. Biol., 1, $1-3$. 
A. Paunksnis is MD (habil.), professor, head of Department of Ophthalmology of Institute for Biomedical Research of Kaunas University of Medicine. In 1969 graduated from Kaunas University of Medicine. Academic achievements: habilitated doctor since 1993, professor of ophthalmology since 1997. Areas of interest are: telemedicine, non-invasive ultrasound ophthalmologic investigation, ophthalmooncology.

A. Mačiulis is an associated professor at Department of Applied Electronics, Kaunas University of Technology. In 1982 graduated Kaunas Polytechnic Institute . In 1998 defended $\mathrm{PhD}$ thesis in informatics science. Since 2000 associated professor. Research areas - digital signal processing, ultrasonic diagnostic devices.

S. Kurapkienè is PhD student at Kaunas University of Technology since 2002. Occupation: engineer at Dept. of Ophthalmology of Institute for Biomedical Research of Kaunas University of Medicine. In 2001 she received master degree in electronics engineering at Kaunas University of Technology. Research areas are ultrasonic diagnostic signal processing, systematization of data, telemedicine.

M.-L. Paunksnienè is an associated professor at Department of Anatomy and Histology, Lithuanian Veterinary Academy. In 1968 graduated Lithuanian Veterinary Academy. In 1982 defended $\mathrm{PhD}$ thesis in biological science. Since 1982 associated professor. Research areas - ultrasonic measurements in veterinary ophthalmology. 


\title{
Žmogaus kataraktos ultragarso slopinimo charakteristiku tyrimas
}

\author{
Alvydas PAUNKSNIS, Audris MAČIULIS, Skaidra KURAPKIENĖ, \\ Marija-Liucija PAUNKSNIENE
}

Šio darbo tikslas buvo įvertinti branduolinès ir diabetinès kataraktos subrendimo įtaką ultragarso slopinimui. Branduolinès kataraktos subrendimas įvertintas LOCS III klasifikacija, lę̌siukas ištirtas ultragarso A-sistema, naudojant $7 \mathrm{MHz}$ dažnio davikli. Ultragarso slopinimo koeficientas lęšiuko branduolyje apskaičiuotas skaitmenizuotų ultragarso signalų spektrinès analizès būdu. Viso ištirti 28 lęšiukai, kurie pagal branduolio subrendimo balus suskirstyti 2 grupes. Nustatyta, kad ultragarso slopinimo koeficientas didesnis, esant labiau išreikštoms branduolio drumstims. İvertinta diabetinès kataraktos subrendimo įtaka ultragarso slopinimui. Ištirti 27 lęšiukai žmonių, sergančiu diabetu, kurie pagal diabeto tipa buvo suskirstyti i I tipo (7 su hemoftalmu - kraujo išsiliejimas i stiklakūni, 7 be hemoftalmo) ir II tipo. Nustatyta, kad ultragarso slopinimo koeficientas didesnis II tipo diabetinès kataraktos grupeje. Manoma, kad taip yra dèl to, kad II tipo diabetu sergančiu žmoniu lęšiuko drumstuma salygoja ne tik diabetiniai, bet ir senatviniai pakitimai. Kataraktos diagnostika nèra sudètinga, tačiau reikalingi neinvaziniai metodai, apibūdinantys kiekybinius lęšiuko pakitimus. Ultragarso slopinimo koeficientas padeda objektyviau įvertinti kataraktos išsivystymo laipsni. 